\title{
2017 Anayasa Değişikliği Sonrası Cumhurbaşkanlığı Kararnamelerine Ait Mahfuz Alan Meselesi
}

Abdülsamet GÜLLER *

Geliş Tarihi (Received): 27.09.2021- Kabul Tarihi (Accepted): 18.11.2021

\section{$\ddot{\mathbf{O z}}$}

Cumhurbaşkanlığı kararnameleri 2017 Anayasa reformundan sonra Türk hukuk gündeminin merkezi kavramlarından bir hâline gelmiştir. Bu durumun en başta gelen sebebi olarak Anayasa değişikliği metninin barındırdığı muğlaklık gösterilebilir. Yürütmeye tanınmış olan kararname gücüne ilişkin tereddütlü alanların başında ise bu yetkinin belirli konular bakımından kanun alanına kapatılarak yürütmeye münhasır kılınıp kılınmadığı yönündeki soru işareti yer almaktadır. Bu bağlamda öğretinin belirgin bir ikilem içinde olduğu ve bu soruya her iki cihette de cevaplar verildiği görülebilmektedir. Sonuçları yönünden bu denli önemli olan bir meseleye cevap ararken tek bir yorumlama biçimine başvurmak yerine, sağlıklı ve geniş kapsamlı bir değerlendirme yapmayı teminen Anayasanın lafzi, sistematik, tarihi ve gaî yorumuna girişmek ve aynı zamanda mümkünse karşılaştırmalı hukuktan yeni sisteme uygun düşecek bir örnek bularak elde edilecek verilerle bir mukayese yapmak daha doğru olacaktır. İşte bu çalışmada doktrinde anılan yorum yollarıyla elde edilen açıklamalar ortaya konulmak ve kararnameler rejimi bakımından yeni Türk sistemine dönük kayda değer açılımlar içeren Fransız uygulaması değerlendirilmek suretiyle ülkemizde yürürlükte olan Anayasa hükümlerinin mahfuz bir alana vücut vermeyeceği düşüncesine erişilmiştir.

Anahtar Kelimeler: Cumhurbaşkanlığı Kararnamesi, Kanun, Yasama Yetkisinin Genelliği, Mahfuz Alan, Münhasır Düzenleme Alanı.

\section{The Question of Reserved Area of Presidential Decrees After the 2017 Constitutional Amendment}

\begin{abstract}
Presidential decrees have become one of the central concepts of the Turkish legal agenda after the 2017 Constitutional reform. The most important reason for this situation can be shown as the ambiguity of the amendment text. The most important problematic area regarding the decree power granted to the executive is the question that ask whether this authority is restricted to the field of law in terms of certain issues and is made exclusive to the executive power. In this context, it can be seen that the Turkish literature is in a dilemma and certain answers are given to this question in both directions. Instead of applying to a single interpretation method when seeking an answer to an issue that's so vital in terms of its results, it would be more accurate to engage in literal, systematic, historical and teleological interpretation of the Constitution in order to have a comprehensive evaluation and at the same time, if possible to find an example from comparative law that fits the new system for comparing. Concordantly in this study, it has been reached the idea that the articles of Constitution in force in Turkey will not give rise to a concept of reserved area, by revealing the explanations obtained through the interpretation methods mentioned in the literature and evaluating the French practice, which includes significant instructions towards the new Turkish system in terms of the decrees regime.
\end{abstract}

Keywords: Presidential Decrees, Law, Generality of the Legislative Power, Reserved Area, Exclusive Regulatory Power.

\footnotetext{
* Dr. Arş. Gör., Hacettepe Üniversitesi Hukuk Fakültesi Anayasa Hukuku Anabilim Dalı,
} abdulsamet.guller@hacettepe.edu.tr 


\section{Giriş}

1982 Anayasasının bünyesinde köklü değişikliklere yol açan ve 2017 tarihli referandum ile kabul edilen 6771 sayılı kanunun, gündeme geldiği andan beridir hukuk dünyasında hatırı sayılır tereddüt ve tartışmaları beraberinde getirdiği açıktır. Siyaset alanında daha çok tercih edilen yeni hükûmet sistemi tasarımı bağlamında konuşulan söz konusu reform, hukukun şekli kaynağı olarak yeni bir norm türü getirmesi sebebiyle, başta anayasa ve idare hukuku olmak üzere bütün hukuk disiplinini ilgilendiren büyük bir dönüşüme sebebiyet vermiştir. Nitekim yürütme yetkisinin sahibi olan Cumhurbaşkanının, önceki uygulamada yer alan son derece kısıtlı ve mahdut uygulama bir yana bırakılırsa geniş bir kapsam yönünden ilk defa olarak klasik kuvvetler ayrılığı teorisinde münhasıran yasama organına bırakılan asli kural koyma gücüyle donatılması, herhâlde yadsınamayacak bir dönüşümdür.

Ancak 6771 sayılı kanunun kural koyma iktidarı açısından bu denli köklü bir dönüşüme imza atan hükümleri, içerdiği bazı müphemlikler dolayısıyla birtakım önemli soru işaretlerini de beraberinde getirmiştir. $\mathrm{Bu}$ kapsamda Cumhurbaşkanlığı kararnamelerinin (CBK) düzenleme alanının tespiti ve bu düzenleme alanı esasen geleneksel olarak yasama organının hareket sahası olduğuna göre, bu alanda her iki kuvvetin karşılaşma zeminin nasıl olacağı açıklığa kavuşturulması gereken soru işaretleri arasında en başta gelenidir. Tabir caizse, öteden beri parlamentoya ait olan ve yürütmenin ancak onun izniyle girebildiği bölgeye, bundan böyle yürütme yeni anayasal çerçeveye göre destursuz bir biçimde girebilecek, bu esnada yasamaya izin yahut icazet anlamlarına gelecek herhangi bir a priori veya a posteriori denetim yolu tanınmayacaktır. Dolayısıyla aynı konuların her iki kuvvet tarafından farklı biçimlerde düzenlenmesi ihtimalinde, bu durumun pozitif hukuka nasıl bir yansıması olacağından başlamak üzere, parlamentonun aslen sahip olduğu yasama yetkisini kullanırken önünde bulduğu yürütmeye karşı başvuracağı, söz konusu yetkiyi yeniden kendisine mal etmesini sağlayacak imkânlara sahip olup olmadığı yollu soru işaretleri bütün gücüyle varlığını duyurmaktadır. Bu kapsamda en can alıcı soru ise, parlamentonun bazı konular bağlamında artık yasama yetkisine sahip olmayıp, bu alanın bundan böyle yürütmeye münhasır kılınmış bir asli düzenleme sahası hâline gelip gelmediği yünündedir. Şu hâlde Meclisin, CBK ile tanzim edilmiş bir konuyu yeniden düzenleyip kendisine mal etme imkânları bir yana, acaba birtakım meseleler bakımından, artık o konunun henüz yürütme tarafından ele alınmamış olsa bile, yasama organına kapalı olup olmadığı yönündeki çarpıcı bir soru cevaplandırılmak üzere karşımızda durmaktadır. Böylesine cesim bir belirsizlik, elbette doktrinin hayal gücünden doğmamış, 2017 Anayasa değişikliklerinin kaleme alınış şekli, bu muğlak alanı epey becerikli bir biçimde türetebilmiştir. 
Belirtmek gerekir ki bütünüyle Anayasanın CBK'ya ilişkin yeni hükümlerinden beslenen mahfuz alan tartışması, gerek doktrinin gerekse uygulamanın gündemini, uzun bir süredir meşgul etmektedir. Verilecek cevaba göre, yasama yetkisinin genelliğini anlatan ve kuvvetler ayrılığı gibi asli kuruculuğa ilişsin son derece esaslı bir tercihe yönelik olan bir prensibin, artık temelli terk edildiği sonucunu doğurma potansiyeli bulunan bir sorunun, öğretide uzun soluklu tartışmalara sebebiyet vermesi elbette şaşırtıcı değildir. Dahası bu yolda üretilen bunca çalışmaya rağmen, bahse konu tartışma yeniden ele alınıp tetkik edilmeye, dolayısıyla bu yolda yeni açılımlara sürekli olarak ihtiyaç bulunmaktadır. Bu çalışma da yeni anayasa hükümleri muvacehesinde yürütmeye mahfuz bir düzenleme alanı tanınıp tanınmadığına ilişskin bu cesim soru işaretine cevaplar arama gayretinin bir neticesidir.

Çalışmanın amacına erişebilmesi için, öncelikle 6771 sayılı kanunla 1982 Anayasasının ilgili maddelerine yerleştirilen CBK çıkarma yetkisine ilişkin hükümler tespit edilmeye ve bu çerçevede, kararname yetkisine taalluk eden yeni kurgu ortaya konulmaya çalışılmaktadır. Akabinde literatürde şu ana kadar ortaya konulan eserlerde mahfuz alan tartışmasına yönelik savunulan görüşler olumlu ve olumsuz cihette olmak üzere derlenmekte, son olarak bu çalışmada benimsenen görüş, gerekçeleriyle birlikte etraflıca açıklanmaya çalışılmaktadır.

\section{Cumhurbaşkanlığı Kararnamelerine Yönelik Anayasal Düzenlemeler}

Cumhurbaşkanlığı kararnamesine konu olabilecek başlıkları belirleyebilmek ve bu tür işlemlerin yasama organının kural koyma gücünün bir ürünü olan kanunlarla olan ilişkisini saptayabilmek için ilk olarak Anayasada bu nevi düzenlemelerin nasıl kurgulanmış olduğunu ortaya koymak gereklidir. Bu kapsamda Anayasa metni boyunca çeşitli maddeler dikkati çekmekle birlikte, Cumhurbaşkanlığı kararnameleri hakkındaki genel hüküm olarak Cumhurbaşkanının yetkilerini düzenleyen 104. maddede karşımıza çıkar. Nitekim maddenin CBK'ya özgülenen 17. fikrası şu suretledir:

$$
\text { Cumhurbaşkanı, yürütme yetkisine ilişkin konularda Cumhurbaşkanlığı }
$$
kararnamesi çıkarabilir. Anayasanın ikinci kısmının birinci ve ikinci bölümlerinde yer alan temel haklar, kişi hakları ve ödevleriyle dördüncü bölümde yer alan siyasi haklar ve ödevler Cumhurbaşkanlı̆̆ kararnamesiyle düzenlenemez. Anayasada münhasıran kanunla düzenlenmesi öngörülen konularda Cumhurbaşkanlı̆̆ kararnamesi çıkarılamaz. Kanunda açıkça düzenlenen konularda Cumhurbaşkanlı̆̆ı kararnamesi çıkarlamaz. Cumhurbaşkanlı̆̆ kararnamesi ile kanunlarda farklı hükümler bulunması halinde, kanun hükümleri uygulanır. Türkiye Büyük Millet Meclisinin aynı konuda kanun çıkarması durumunda, Cumhurbaşkanlı̆̆ kararnamesi hükümsüz hale gelir. 
Cumhurbaşkanının asli düzenleme gücünün kapsamını saptama noktasında başvurulacak diğer bir hüküm, yine aynı maddenin 9. fikrasında yer alır. Bu fıkrada, üst kademe yöneticilerin atanmasına ilişkin usul ve esasların CBK ile tanzim edileceği belirtilmiştir. Cumhurbaşkanlığı kararnamelerine yönelik başka bir hüküm olarak, 106. maddenin son fıkrasında "Bakanlıkların kurulması, kaldırılması, görevleri ve yetkileri, teşkilat yapısı ile merkez ve taşra teşkilatlarının kurulması(nın) Cumhurbaşkanlı̆̆ı kararnamesiyle” düzenleneceği hususu karşımıza çıkmaktadır. Ayrıca 108. maddenin son fikrasında, Devlet Denetleme Kurulunun işleyişi, üyelerinin görev süresi ve diğer özlük işlerinin; 118. maddenin son fikrasında ise Milli Güvenlik Kurulu Genel Sekreterliğinin teşkilatı ile görevlerinin CBK ile saptanacağı söylenmektedir. Son olarak kamu tüzel kişiliklerinin kanunla düzenleneceğini amir olan 123. maddenin son fikrasına, 6771 sayılı kanunla "veya Cumhurbaşkanlığı kararnamesiyle" ibaresi eklenmek suretiyle, kararname çıkarma gücünün bu alanda da yetkili olduğu belirtilmiştir.

Şu hâlde Anayasada CBK çıkarma iktidarına yönelik kurgulanan çerçeveye bakıldığında genel hüküm mesabesindeki 104. maddenin 17. fikrasına ek olarak, Anayasanın değişik maddelerinde birtakım özel hükümler de ihdas edilmekte ve belirli spesifik konular yönünden CBK çıkarma yetkisi özel olarak vurgulanmaktadır. 17. fikradaki "yürütme yetkisine yönelik konular" genel ölçüsü dışında Anayasada ayrıca sayılan başlıklar şu şekildedir:

- $\quad$ Üst kademe yöneticilerin atanmasına yönelik usul ve esaslar (m. 104/9),

- $\quad$ Bakanlıkların kurulması, kaldırılması, görevleri ve yetkileri, teşkilat yapısı ile merkez ve taşra teşkilatlarının kurulması (m. 106/son),

- $\quad$ Devlet Denetleme Kurulunun işleyişi, üyelerinin görev süresi ve diğer özlük işleri (m. 108/son),

- Milli Güvenlik Kurulu Genel Sekreterliğinin teşkilatı ile görevleri (m. 118/son)

- $\quad$ Kamu tüzel kişiliklerinin kurulması (m. 123/3)

Cumhurbaşkanının kararname yetkisine ilişkin genel hüküm olan 104. fikranın 17. fıkrası ile diğer düzenlemelerden anlaşıldığı üzere, Cumhurbaşkanlığı kararnamelerine, münhasıran yürütme yetkisine ilişkin hususlar konu edilebilecektir. Ancak tali anayasa koyucu, CBK'nın konusuna ilişkin bu genel kriterle yetinmemiş ve bazı alanları (temel hak ve hürriyetler vs.), bu kapsama girse bile kararname yetkisinin konusu olmaktan çıkarmıştır. Bundan başka bazı başlıkların Cumhurbaşkanlığı kararnamesi ile düzenleneceği de ayrıca ifade edilmekte ve vurgulanmaktadır. Bu konuların 104. maddenin 17. fikrasında belirtilen yürütme yetkisinin kapsamına dâhil edilmesinin mümkün oluşuna rağmen ayrıca ve yeniden vurgulanması, söz konusu başlıklar bakımından acaba yürütmeye mahfuz bir alan mı tanınmak 
istenmiştir, istikametinde bir tereddüde sebebiyet vermiştir (Özbudun, Türk Anayasa Hukuku, 2017, s. 251). Nitekim 123. maddenin 3. fikrasındaki kanununun yanı sira CBK ile de yapılabileceği belirtilen kamu tüzel kişiliklerinin kurulması örneği hariç ilk dört başlık bakımından, bu konularda tıpkı sonuncu başlıkta olduğu gibi kanun ve CBK demek yerine yalnızca CBK'dan bahsedilmesinin, bu yöndeki belirsizliklere önemli bir haklılık payı verdiği yadsinamaz.

Ülkemizde uygulanan yeni sistemin, gerek kuvvetlerin iş bölümü yönünden gerekse norm koyma iktidarının sağlıklı bir biçimde işleyebilmesi cihetiyle çözülmeyi bekleyen son derece hayati bir problemi olan bu belirsizlik karşısında, öğretinin büyük bir ikilem içinde olduğu görülebilmektedir. Gerçekten 6771 sayılı kanun daha ilk gündeme geldiği andan başlayarak bugüne değin üretilen ders kitabı, monografi, makale ve sair bilimsel çalışmalardan tespit edilebildiği üzere, anayasanın bahse konu tasarımının CBK'ya ait bir mahfuz alana vücut verdiği görüşü de, tam aksine olarak yeni anayasal kurgudan böylesine bir alanın çıkarılamayacağı ve yasama yetkisinin genelliği prensibinin mükemmelen devam ettiği kanaati de tereddütsüz biçimde savunulabilmektedir. Gelinen noktada artık yargı organı da görüşünü bildirme firsatı bulabilmiş ve bu tartışmaya katılmış bulunmaktadır. Biz de bu küçük incelemede, hâlen daha tüketilmemiş olan söz konusu meseleyi ele alırken, bu çalışmada benimsenen görüşe gelmeden önce, ilk olarak literatürden derlenebilecek yaklaşımları tespit etmek istiyoruz.

\section{Mahfuz Bir Alanın Bulunduğu Yönündeki Görüsşler}

2017 Anayasa değişiklikleri kabul edildiğinden beridir, Anayasanın CBK'ya yönelik düzenleme şeklinden beslenen kararnamelere münhasır kılınmış bir düzenleme alanının mevcudiyetini ispatlamak üzere çok sayıda gerekçe ortaya konulmuştur. Bu bahse yönelik doktrinde görüş bildiren yazarları burada tek tek göstermek ve açıklamak yerine, çoğu gerekçenin aynı anda çok sayıda yazar tarafından savunulması da göz önünde tutularak, yalnızca tespit edebildiğimiz görüşleri madde madde sıralamakla iktifa edeceğiz. Bu bağlamda saptayabildiğimiz açıklamalar şunlardır:

1. Cumhurbaşkanlığı kararnamesiyle düzenleneceği kaleme alınan hususların zaten yürütme yetkisine ilişkin olmasına ve bu itibarla genel hüküm olan 104. maddenin 17. fikrası çerçevesinde bu alanlarda CBK çıkarılmasının mümkün bulunmasına rağmen, ilgili maddelerde bu başlıkların Cumhurbaşkanlığg kararnamesiyle düzenleneceğinin ayrıca ve yeniden belirtilmesi, bu kapsam yönünden münhasır bir düzenleme alanına işaret etmektedir (Atar, 2019a, s. 198-199; Yasin, 2019, s. 318-319; Aslan, 2019, s. 144; Yeniay ve Yeniay, 2019, s. 113-114; Aç11, 2018, s. 735). 
2. Mahfuz alanın varlığı Anayasanın lafzi yorumundan istidlal edilebilir. Nitekim Cumhurbaşkanlığı kararnamesine yönelik genel yetki olan 104. maddenin 17. fikrasında ihtiyari bir anlam barındıran "çıkarılabilir" lafzına karşılık, anılan maddelerde bu defa zorunluluk içeriği taşıyacak şekilde “düzenlenir” denilmesi, Anayasa koyucunun her iki durum bakımından iki farklı seçimde bulunduğunu açıkça göstermektedir (Gözler, 2019b, s. 932; Ülgen, 2018, s. 19-20; Kanadoğlu, 2018, s. 647; Azakl1, 2019, s. 77; Yeniay ve Yeniay, 2019, s. 113).

3. Yeni sistemde yürütme organına tanınan münhasır düzenleme alanına, Anayasanın sistematik yorumundan da ulaşılabilir. Buna göre, 104. maddenin 17. fikrası ve 123. madde ile CBK çıkarmaya yönelik diğer maddeler arasında genel-özel hüküm bağlantısı kurulmalıdır. Nitekim m. 104/17'de Anayasada münhasıran kanunla düzenleneceği öngörülen hususlarda CBK çıkarılamaz denilmekte, 123. maddenin ilk fikrasında da idarenin kanunla düzenleneceği belirtilmektedir. Bu ikinci hüküm, esasen bütün idari teşkilat açısından genel hüküm mesabesindedir. Öte yandan idari teşkilat içinde yer alan bakanlıklar (m. 106/son), Milli Güvenlik Kurulu (m. 118/son) ve Devlet Denetleme Kurulunun (m. 108/son) CBK ile düzenleneceği ayrıca ve özel olarak ifade edilmektedir. Öyleyse bu başlıklar, Anayasada ifadesini bulan “idarenin kanunla düzenlenmesi ilkesi”ne bizzat Anayasanın getirdiği istisnalar olarak karşımıza çıkmaktadır. Benzer şekilde, 128. maddenin 2. fikrasında, memurların ve diğer kamu görevlilerinin nitelikleri, atanmaları, görev ve yetkileri, hakları ve yükümlülükleri ile özlük haklarının kanunla düzenleneceği hüküm altına alınmaktadır. Bu düzenleme karşısında, Cumhurbaşkanının, üst kademe yöneticilerinin atanmasına ilişkin usul ve esasları CBK ile düzenleyeceğini belirten 104. maddenin 9. fikrası, özel hüküm niteliğindedir. Şu hâlde anılan özel hükümler yoluyla esasen münhasır kanun alanına giren konuların bazıları, bundan böyle münhasır bir CBK sahasına dönüştürülmektedir. Çünkü yorum ilkeleri gereği bir genel hüküm ile özel hükmün karşılaştı̆̆g durumlarda, genel hüküm değil özel hüküm uygulama alanı bulur. Binaenaleyh, bu hususların kanun konusu yapılamayacağını ifade eden açık bir hükme gerek olmaksızın, ilgili başlıklar mahfuz bir CBK alanına dönüşmüştür (Eren, 2019, s. 43-44; Narter ve Kaya, 2020, s. 267; Küçük ve Doğan, 2019, s. 47-49; Duman, 2019, s. 551).

4. 123. maddenin 3. fikrasında kamu tüzel kişiliğinin hem kanunla hem CBK ile kurulabileceğinin özellikle vurgulanması, Cumhurbaşkanlığı kararnamesiyle tanzim edileceği belirtilen dört madde bakımından da bir karşılığa sahiptir. Nitekim Anayasa koyucunun bu hususlarda aynı zamanda kanun çıkarılabileceğini de düşünüyor olması durumunda, 123. maddede ayrıca kanunla düzenleme yapılabileceğinin söylenmesine ihtiyaç kalmayacaktır. Şu var ki 123. maddede CBK'nın yanı sıra kanunla da düzenleme yapılacağı vurgulandığına göre, 
Anayasa koyucu CBK konusu olacağı öngörülen bu maddeler cihetiyle bir münhasır alan üretmek istemiştir (Atar, 2019b, s. 257; Gözler, 2019a, s. 373; Yasin, 2019, s. 318; Y1lmaz, 2020, s. 241; Aç11, 2018, s. 735; Yeniay ve Yeniay, 2019, s. 113).

5. Anayasanın Geçici 21/B maddesinde, CBK ile düzenleneceği belirtilen değişikliklerin, Cumhurbaşkanının göreve başlama tarihinden itibaren en geç altı ay içinde düzenleneceği hüküm altına alınmıştır. Cumhurbaşkanının, 104. madde bağlamındaki yürütmeye dair konulara ve 119. maddedeki olağanüstü hâle ilişkin düzenleme yetkileri takdiri mahiyette olduğundan, altı ay içinde düzenleme mükellefiyetinin bu dört maddeye yönelik olması icap eder. Binaenaleyh söz konusu geçici maddede ifadesini bulan bu hüküm mahfuz alan düşüncesini desteklemektedir (Yıldırım, 2017, s. 27; Ülgen, 2018, s. 19-20; Narter ve Kaya, 2020, s. 267-268; Duman, 2019, s. 550).

6. Yürütme organına ait bir mahfuz düzenleme alan fikri esasen yeni değildir ve 2017 Anayasa değişiklikleriyle peyda olmamıştır. Zira 1982 Anayasasının özgün metninde 107. madde ile çerçevesi çizilen Cumhurbaşkanı kararnamelerinin yürütmeye tanınan münhasır bir sahaya karşılık geldiği o dönem doktrinde hâkim görüş olarak yerleşmiştir. Referandumdan sonra ortaya çıkan yeni sistemde de aynı durumun kabul edilmemesi için bir sebep yoktur (Yasin, 2019, s. 318-319; Aksoylu Ürger, 2018, s. 146; Y1lmaz, 2020, s. 240-241; Özdemir, 2019, s. 275-276).

7. Mahfuz alana yönelik tartışmalar, 2017 Anayasa değişikliklerinin, Türk siyasi hayatında oldukça uzun süredir yaşanmakta olan yürütmeyi güçlendirme eğiliminin bir sonucu olması göz önünde tutularak düşünülmelidir. Nitekim Anayasa değişikliklerinin genel gerekçesinde eski dönemlerde karşılaşılan hükûmet istikrarsılıklarından bahsedildiği görülmektedir. 2017 reformunun başlıca gayeleri arasında kendine yer bulan ve ülkemizde uzunca bir süredir varlık kazanan bahse konu eğilimin sonucu olan güçlü yürütme arayışının, Cumhurbaşkanlığı kararnamelerine mahfuz bir alan tanınmaksızın sağlanması mümkün değildir. Zira yasama ve yürütme organlarının farklı siyasi cenaha dayanması ihtimalinde yürütmeyi, yasamanın muhtemel blokajlarından koruyarak sistemin Anayasa değişiklikleri ile amaçlanan istikrara kavuşması sağlanmış olacaktır. Öyleyse yeni tasarımda CBK'ya ait bir mahfuz alanın bulunması gerekir (Barın, 2020, s. 63-68; Duman, 2019, s. 551).

8. Anayasada münhasırlık ifade eden herhangi bir ibare bulunmadığı hâlde öğretide yalın bir şekilde kanunla düzenleneceği belirtilen maddelerin münhasır kanun alanı teşkil edeceği kabul edilmektedir. Bu kabulün, benzer şekilde CBK'lar yönünden de geçerli olması ve Cumhurbaşkanlığı kararnamesiyle düzenlenir denilen maddelerde aynı mantıkla münhasır bir CBK alanının bulunması gerektiği savunulabilir (Barın, 2020, s. 70-71). 
Bundan başka Venedik Komisyonu da, Anayasa değişiklik teklifine dair raporunda bahse konu başlıkların CBK bakımından mahfuz alan teşkil edeceğine yönelik yorumlamayı yeğlemekte olduğunu şu şekilde ortaya koymuştur:

"Yasamanın, Cumhurbaşkanlığı kararnamelerinden üstün kabul edileceği ilkesi, Cumhurbaşkanının yasama gücüne denetim getirdiği için memnuniyetle karşılanmaktadır. Bununla birlikte, hangi alanların kanunla, hangi alanların Cumhurbaşkanlı̆̆l kararnameleriyle düzenleneceği konusundaki hükümlerle müştereken yorumlanması gerekecektir. Yalnızca kararnamelerle düzenlenecek - son derece mühim - alanlarda TBMM'nin kanun koyması mümkün olmayacak ve Cumhurbaşkanlı̆̆ kararnameleri geçerli olacaktır” (Venedik Komisyonu, 2017).

Anayasanın yeni çerçevesinin kararnameler yönünden mahfuz bir alana vücut verdiği yolundaki tercihin, norm koyma gücünün uygulandığı alan bakımından önemli bir yansıması olmaktadır. Buna göre, Anayasada yürütme organına münhasır bir kararname alanının tanınmış olduğu yaklaşımının kabul edilmesi hâlinde, zorunlu olarak yeni sistem bakımından kural konulabilecek alanlar itibariyle üçlü bir ayrımın kabul edilmesi de gerekecektir. Gerçekten mahfuz alanın mevcut olduğunu savunan yazarların (Gözler, 2019a, s. 367 vd; Eren, 2019, s. 40-46; Ülgen, 2018, s. 16 vd; Y1lmaz, 2020, s. 229 vd; Narter ve Kaya, 2020, s. 249-272; Aksoylu Ürger, 2018, s. 138; Yeniay ve Yeniay, 2019, s. 122), bu gerekliliğin bir neticesi olmak üzere norm alanını şöyle sınıflandırdıkları görülür:

Münhasır kanun alanı (yasak alan), 104. maddenin 17. fikrasında Cumhurbaşkanlığı kararnamesi çıkarılamayacağı öngörülen meselelerden meydana gelmektedir. Buraya dâhil olan konularda CBK çıkarılması yasak olduğundan, bu alanda yalnızca kanun yapılabilecektir.

Münhasır Cumhurbaşkanlığı kararnamesi alanı (mahfuz alan), Anayasada CBK ile düzenleneceği ayrıca gösterilen hususlardır. Cumhurbaşkanının saklı yetkisini oluşturduğundan bu sahada kanun çıkarılması mümkün değildir.

İhtiyari alan (ortak-paylaşımlı alan), Münhasır kanun alanı ile münhasır Cumhurbaşkanlığı kararnamesi alanının dışında kalan konulardan yürütme yetkisine yönelik olan her mesele buraya dâhil olacaktır. 104. maddenin 17. fikrası muvacehesinde bu konulara ilişkin kanun ve CBK çıkarılabilir.

Bu şemanın, yeni sistemde Cumhurbaşkanının mahfuz düzenleme yetkisinin varlığını kabul etmenin zorunlu ve tabii bir neticesi olarak karşımıza çıktığını, dolayısıyla sadece bu yöndeki tercihin benimsenmesi hâlinde varlık bulabileceğini tekrar etmekte fayda 
bulunmaktadır. Şu hâlde karşı görüşe ram olan yazarlar bakımından, bu tür bir kategorizasyon hiçbir şekilde mevcut veya olanaklı değildir. Şimdi de söz konusu karşı yaklaşıma temas edilecektir.

\section{Mahfuz Alanın Bulunmadığı Görüşü}

Anayasanın sistematiğinden münhasıran yürütme organına bahşedilmiş bir düzenleme alanının çıkarılamayacağı kanaati doktrindeki pek çok yazar tarafından savunulmuştur. Dahası bugün gelinen noktada, Cumhurbaşkanlığı kararnamelerine dönük bilimsel çalışmalar gözden geçirildiğinde, hâkim yaklaşımın bu yönde olduğunu söyleyebilmek mümkündür. Bu kapsamda şu ana kadar çok sayıda farklı argüman ortaya konulmuş ve 1982 Anayasasının hem 6771 sayılı kanunla getirilen yeni hükümleri, hem de değişiklikten önce de mevcut olan düzenlemeleri çerçevesinde, mahfuz alan düşüncesine herhangi bir dayanak bulunmadığı belirtilmiştir. Bu doğrultuda ortaya konulan gerekçeler derlendiğinde karşımıza şöyle bir tablo çıkar:

1. Anayasanın 7. maddesi gereğince yasama yetkisi Türk Milleti adına Türkiye Büyük Millet Meclisine verilmiş ve söz konusu yetkinin devredilemeyeceği ifade edilmiştir. Yasama organının yetkilerini belirleyen 87. maddede ise Meclisin, hiçbir tahdit, tanımlama yahut çerçevelemeye tabi tutulmaksızın genel ve mutlak şekilde kanun koyma yetkisini haiz olduğu belirtilir. Öte yandan yürütme yetkisini tanzim eden 8. madde, bu gücün Cumhurbaşkanınca Anayasaya ve kanunlara uygun olarak kullanılacağını hüküm altına alır. Dolayısıyla anılan maddelerde ne yasama yetkisinin sınırlandırılmasına dönük ne de yürütmenin Meclis karşısında sahip olacağı mahfuz bir alanın varlığına dair herhangi bir vurguya denk gelinmektedir (Tan, 2018, s. 73; Ulusoy, 2019, s. 303-304; Ardıçoğlu, 2017, s. 37-38; Atay, 2019, s. 56; Çıtak, 2019, s. 35-36; Okşar, 2019, s. 136 vd; Akartürk, 2020, s. 12; Akyılmaz, 2019, s. 197-198).

2. Bazı hususların Cumhurbaşkanı kararnamesi aracılığıyla düzenleneceğinin ifade edildiği maddelerde de, bu konuların sırf CBK ile düzenlenebileceğine veya ilgili alanda kanun konulamayacağı anlamını doğuracak hiçbir açık hüküm yer almamıştır. Binaenaleyh Anayasada açıkça kendisine dayanak bulan yasama yetkisinin genelliği ilkesini izale edecek hiçbir gerekçe, 6771 sayılı kanundan sonra bile Anayasa metninden çıkarılamamaktadır (Özbudun, 2019, s. 288; Günday, 2017, s. 659; Tanör \& Yüzbaş10ğlu, 2019, s. 404).

3. İdarenin kanuniliği prensibinin anayasal temelini teşkil eden 123. maddenin 1. fikrasının aynen korunduğu görülmektedir. Bu durumda, idarenin kuruluşuna yönelik olması itibariyle bahse konu başlıklarda CBK ile düzenleme yapılması, eğer bu dört madde kabul edilmeseydi mümkün olmayacaktı. Şu hâlde anılan dört madde, ilgili konular cihetiyle 123. maddeye istisna getirmiştir. Böylesine bir istisna hükmü, ancak ve ancak bu konularda CBK 
çıkarılmasına imkân verebilir. Bunun çok daha ötesine giderek, bu hususlarda bundan böyle kanun çıkarılamayacağı neticesine, ortada herhangi bir açıklık bulunmamasına rağmen yorum yoluyla ulaşmak, önde gelen yorum yöntemleri arasında bulunan istisnaların dar yorumlanması ilkesine açıkça ters düşecektir (Sever, 2020, s. 359; Tekinsoy, 2020, s. 389 vd.).

4. Anayasanın 104. maddesinin 17. fikrası ile CBK'ların bağlı olacağı hukuki rejim belirlenmiş bulunmaktadır. Buna göre, daha önceden kanunla düzenlenmiş bir meselede CBK çıkarılamayacağı gibi, CBK çıkarıldıktan sonra aynı konuda kanun yapılması durumunda ilgili kararname hükümsüz hâle gelecektir. Anayasa, kanun ve CBK arasında geçerli olan bağı bu denli açık şekilde ortaya koymuşken ve bahse konu dört madde bu rejime istisna oluşturacak bir hükme yer vermemişken, Cumhurbaşkanlığı kararnameleri bakımından Anayasada öngörülmüş olan statüyü değiştirecek böylesine bir çıkarım hiçbir şekilde isabet taşımayacaktır (Ardiçoğlu, 2017, s. 37-38; İba, 2018, s. 246).

5. Anılan başlıkların yürütmenin düzenleme yetkisine münhasır sayılması hâlinde, bu konularda çıkarılan CBK'lar adeta kanuna eşdeğer bir niteliğe bürünebilir. Bu ise 119 . maddede, 104. maddeden ayrıştırılan, farklı bir rejime tabi kılınarak açıkça kanun hükmünde olduğu ilan edilen olağanüstü hâl Cumhurbaşkanlığı kararnamesine verilmiş bir statünün, Anayasaya aykırı biçimde olağan dönemlerde çıkarılan Cumhurbaşkanlığı kararnamelerine tanınması sonucunu doğuracaktır. Böyle bir neticenin, her iki tür kararnameyi de birbirinden farklı statülerde düzenlemek istemiş olan Anayasa koyucunun amacıyla bağdaştığını söyleyebilmek zordur (Fendoğlu, 2019, s. 284-285).

6. 2017 değişikliklerinden önce 107. madde ile çerçevesi çizilmiş olan Cumhurbaşkanlığı kararnamelerinin doktrinde o dönem Cumhurbaşkanına ait mahfuz bir düzenleme alanı olarak kabul edildiği, bu durumun, yeni sistemde biraz daha genişlemek suretiyle devam ettiği düşüncesi de kabul edilmemelidir. Çünkü eski uygulamada yer alan Cumhurbaşkanlığı kararnameleri, sadece Cumhurbaşkanlığı Genel Sekreterliğinin düzenlenmesi bağlamında son derece dar ve kısıtlı bir alana karşılık gelirken, yeni düzende artık kişilere doğrudan veya dolaylı olarak ödev yükleyen hükümler getirilmesi mümkündür. Dahası bu norma dönük hukuki rejim Anayasada tümden yenilenmiş, 107. madde ilga edilmek ve 104. maddenin 17. fikrası değiştirilmek suretiyle baştan sona farklı bir hukuki statü kabul edilmiştir. Şu hâlde 2017 öncesi ile bugünün Cumhurbaşkanlığı kararnameleri arasında isim benzerliği dışında bir rabıta aramak doğru değildir (Ardıçoğlu, 2017, s. 36-37; Yıldırım, 2019, s. 300-301).

7. Anayasa koyucunun iradesi eğer yürütme organına münhasır bir düzenleme alanı tahsis etmek yönünde olsayd1, yasama ve yürütme ilişkilerinin yeniden çerçevelenmesi 
sonucunu doğuran, dolayısıyla son derece radikal bir dönüşümü beraberinde getiren böylesine bir meselede, Anayasanın özerklik hakkında açık bir hükme yer vermesi zaruri olurdu. Ne var ki Anayasada buna ilişkin herhangi bir sarahat yer almamıştır (Söyler, 2018, s. 121).

8. Esasen Anayasalarda yürütme organına münhasır kılınmış bir düzenleme alanı tanınması bütünüyle bir tercih meselesidir ve dilerse kurucu iktidarın bunu hayata geçirmesi pekâlâ mümkündür. Dahası bunun dünya anayasalarında örneği de mevcuttur. Ancak böyle bir sonuca nasıl ulaşılacağının yöntemleri de bellidir. Nitekim Anayasadan bu tür bir anlamın çıkarılabilmesi için 1958 Fransız Anayasası örneğindeki gibi kural koyma gücünün yasama ve yürütme arasında belirli konular yönünden paylaştırıldığının açıkça belirtilmesi icap eder. Zira yasama yetkisinin genelliği gibi temel bir prensibin bırakılması manasına gelecek böyle bir dönüşümü benimsemiş olan Anayasa koyucunun, bunu şüphesiz açık ve net bir biçimde yapması beklenir. Aksi hâlde böyle bir çıkarıma yalnızca yorum yoluyla varmak yerinde bir yaklaşım değildir (Anayurt, 2019, s. 324-326). 2017 Anayasa değişikliklerinde ise bu ölçüde bir netlik bulunmadığg açıktır (Keskinsoy, Kaya ve Meri, 2020, s. 1400-1401).

9. Anayasada yürütmeye yönelik münhasır düzenleme alanının açıkça hüküm altına alındığı Fransız örneğinde yargı kararları, söz konusu alanda Parlamentonun düzenleme yapabileceğini kabul etmektedir. Dolayısıyla karşılaştırmalı hukukta yürütmenin mahfuz düzenleme alanının anayasayla net bir biçimde tanındığı örnekte dahi ortaya çıkan eğilim, Meclisin yetkisini genişletme yönündedir (Ulusoy, Aralık 2016 Anayasa Teklifi Neler Getiriyor, Neler Götürüyor, s. 7; Sevgili Gençay, 2020, s. 237-274).

10. Yukarıda ifade edildiği üzere Anayasa değişikliği metninde, yürütmeye tanınmış mahfuz bir alanı açıklayan hiçbir hüküm yer almadığı gibi, böyle bir sonuca gerekçede de denk gelebilmek mümkün değildir. Gerçekten Anayasa değişikliği teklifinin gerekçesinde bu manaya gelebilecek en ufak bir beyanat veya vurgu yoktur (Söyler, 2018, s. 121).

11. Son olarak, konun koyucunun da böyle bir mülahazaya iltifat etmediği görülmektedir. Nitekim Anayasada kararname ile düzenleneceği ayrıca belirtilen konularda Cumhurbaşkanının düzenleme yapılabilmesini temin edebilmek için, önce yürürlükte bu alanlara müteallik olan kanunlar kaldırılmış ve ilgili düzenleme alanı adeta Cumhurbaşkanlığı kararnamesi için boşaltılmıştır. Eğer münhasır alan tezi uygulayıcılar tarafından kabul edilmiş olsaydı, kuşkusuz böyle bir harekete ihtiyaç duyulmayacağı aşikârdır (Sever, 2020, s. 359).

Cumhurbaşkanlığı kararnamelerinin norm koyma alanı bağlamında kanunlarla olan ilişkisine yönelik karşımıza çıkan en can alıcı sorunlardan biri olan mahfuz alan meselesine, literatürde olumlu ve olumsuz yönde verilen cevaplar ile buna ilişkin gerekçeleri bu suretle 
ortaya koymuş bulunuyoruz. Görüldüğü üzere, bu önemli soruya öğretinin yabana atılamayacak bir kısmı olumlu cevap verirken, hatırı sayılır bir kısmı ise, Anayasadan böyle bir anlamın çıkarılmasının, gerek önceki gerekse yeni hükümler bağlamında mümkün olmadığı yaklaşımını benimsemektedir. Öte yandan mahfuz alanın bulunup bulunmadığına ilişkin soruya verilen cevapların, bu iki yaklaşımdan ibaret olmadığı söylenmelidir. Gerçekten öğretide bazı yazarların, bahse konu soruya başka çözümler önerdikleri görülebilmektedir. Şimdi de mahfuz alana ilişkin tartışmaları değerlendirmeden önce bu görüşlere göz atacağız.

\section{Mahfuz Alan Sorununa Yönelik Daha Farklı Yaklaşımlar}

Anayasada 6771 sayılı kanunla yasama ve yürütmenin asli düzenleme gücüne dair kurgulanmış olan yeni çerçevenin anlaşılmasında, yalnızca mahfuz alanın mevut olduğu veya olmadığı cevabının verilmesinin yeterli olmayacağını savunan yazarlar da dikkati çeker. Bu bağlamda ilk olarak Şirin'in ortaya koyduğu yaklaşıma bakacak olursak yazarın öncelikle Anayasanın hiçbir yerinde yazmayan münhasır CBK sahasının kabul edilmemesi gerektiğini düşüncesini benimsediği görülmektedir. Fakat yazar, bununla yetinmeyip devamında, 104 . maddenin 17. fikrasında hüküm altına alınan, kanunda açıkça düzenlenen husularda CBK çıkarılamayacağı yönündeki kayıtlamayı yorumlamakta, böylece “Cumhurbaşkanlığı kararnamesiyle düzenlenir" ibaresinin geçtiği meselelerin, bu kuralın istisnasını teşkil edeceğini belirtmektedir. Netice itibariyle yazara göre, bahse konu hususlar yürütmeye ait mahfuz bir alana vücut vermemekte ve fakat önceden bu sahada bir kanun yapılmış olması CBK çıkarılmasına da engel teşkil etmeyecektir. Dolayısıyla yazara göre anılan dört konuya ilişkin bir kanun çıkarılmış olması, bu konuların daha sonra CBK ile düzenlenmesine engel değildir. Hasılı Anayasa koyucu bu maddeleri kabul ederken, bir mahfuz alan üretmek yerine, anılan başlıklarda kanunun yanı sıra Cumhurbaşkanlığı kararnamesinin de çıkarılmasını arzu etmiştir (Şirin, 2018, s. 335).

Buna benzer bir tasarlayış, birtakım nüanslarla Can tarafından da savunulmuştur. Nitekim yazara göre, anılan dört başlık bağlamında kanuna kapatılmış bir sahanın mevcudiyetini iddia etmenin, değişikliklerden sonra bile Anayasada korunmuş olan genel ilkelerle bağdaşmasına imkân bulunmamaktadır. Bununla birlikte 104. maddenin 17. fıkrasındaki esaslara göre, kanun çıkarılması durumunda ilgili konuların artık CBK ile düzenlenemeyeceğini söylemek de, bu maddelerdeki “düzenlenir” lafzıyla Cumhurbaşkanına açık ve net bir biçimde tanınmış olan yetkinin geçersiz sayılması neticesini doğuracağı için benimsenmemelidir. Öyleyse 6771 sayılı kanunun getirdiği hükümlerle, Anayasada yer alan ve herhangi bir değişikliğe uğratılmayan genel prensipleri bağdaştıracak bir yaklaşım geliştirilmelidir. Buna göre ilgili alanlar yönünden ya kanunla veya kararnameyle düzenleme 
biçiminde bir tercih yapma zorunluluğu yerine, birlikte ve bir arada düzenleme yapılmasının mümkün olduğu kabul edilmelidir. Burada her iki normun yetki sahası arasındaki ayrım, "konu" yerine "derinlik" temelli olması gerektiği söylenebilir. Bu durumda, kanun koyucu “Cumhurbaşkanlığı kararnamesi ile düzenlenir.” denilen başlıklarda, sadece genel ve çerçeve niteliğinde kanun çıkarabilecek ve bu hususlarda kararname çıkarılmasını gereksiz bırakacak ölçüde detaylı düzenleme yapamayacaktır. Geriye kalan meselelerin düzenlenmesi ise, asli bir yetki olarak tasarlanmış olan CBK'ya ait olacaktır. Dolayısıyla bahse konu dört başlığın temelli olarak Parlamentoya kapatılmış olduğunu savunmak yerine, burada, mahfuz alanın konuyla ilgili olmadığg ve fakat düzenlemenin derinliğine yönelik olduğu söylenebilir (Can, 2020, s. 150-157).

Bu konuda ilginç bir düşünce Sezer tarafindan ortaya koymuştur. Buna göre, Anayasada ayrıca ve hususi olarak belirtilen dört konu bakımından sadece CBK çıkarılabilir yerine önce CBK çıkarılabilir anlamı doğmaktadır. Şu hâlde yasama organının bu alanda henüz Cumhurbaşkanlığı kararnamesi çıkarılmamışsa kanun yapması mümkün değildir. Buna mukabil bir kere CBK çıkarıldıktan sonra artık Meclisin o konuda kanun yapmasının önünde bir engel kalmaz. Sonuç olarak bahse konu dört madde kapsamında mahfuz bir yetki değil, bir “öncelikli düzenleme alanı” getirilmiş olmaktadır (Sezer, 2019, s. 376-378).

Son olarak Fendoğlu'nun geliştirdiği yaklaşıma bakılacak olduğunda, yazarın mahfuz alana ilişkin üçlü bir kategori meydana getirdiği görülür. İlk kategori, Anayasada ayrıca belirtilen dört başlığa ilişkin olup, bu kısım sert mahfuz alanı oluşturmakta ve bu hususlar münhasıran CBK ile düzenlenebilmektedir. İkinci kategori, esnek mahfuz alan olarak adlandırılabilir. Burası, 104. maddenin 17. fikrasında belirlenen hudutlar muvacehesinde yürütme yetkisine ilişkin konulardan oluşmaktadır. Bu kapsamda CBK'nın yanında kanun da çıkarılmış olması hâlinde kanun yeğlenecektir. 3. kategori ise, 123. maddenin 3. fikrası çerçevesinde kamu tüzel kişiliğinin kurulmasından ibarettir. Anayasa koyucu bu alanı kanuna ve CBK'ya bırakmıştır. Ne var ki önce CBK çıkarılmış olması hâlinde, artık o konu mahfuz alana dönüşecek ve kanun çıkarılması mümkün olmayacaktır (Fendoğlu, 2020, s. 687 vd.).

Böylece Türk doktrininde mahfuz alan sorununa yönelik umumiyetle ortaya konulan görüşleri derlemiş bulunuyoruz. Takip eden başlıkta ise, söz konusu problemin nasıl anlaşılması gerektiği üzerinde kafa yorulacaktır.

\section{Mahfuz Alan Sorusu Nasıl Cevaplanmalıdır?}

2017 Anayasa değişiklikleri ile hayata geçirilen yeni düzende, yasama ve yürütme kuvvetleri arasında bölüştürülen kural koyma gücüne yönelik en büyük tartışma alanlarının 
başında yürütmeye tanınmış münhasır bir düzenleme sahasının mevcudiyetine dönük tereddütlerin geldiği, yukarıda bütün çıplaklığı ile aktarılan öğretideki derin görüş ayrılığının çapı karşısında yadsınamaz bir gerçek olarak kendini gösterir. Gerçekten Türk doktrininin, Anayasanın Cumhurbaşkanlığı kararnamelerine yönelik hükümleri bağlamında neredeyse ikiye bölünmüş olduğunu söylemek abartı olmayacaktır. Yukarıda gösterildiği gibi, bu soru işaretine ilişkin her iki yöndeki kanaati de destekleyecek çok sayıda argüman getirilmiştir. Bu kapsamda meseleyi en azından uygulama bakımından kesin olarak bir neticeye bağlayacak olan Anayasa Mahkemesinin içtihatları kararlılık bulana kadar, daha farklı açıklama ve gerekçelerin de ortaya konulması muhtemeldir. Bu çalışma da, belirtildiği üzere, şu ana kadar önerilmiş olan farklı yaklaşımların derlenmesi ve bahse konu meselenin değerlendirmesi suretiyle anılan tartışmaya katkıda bulunma amacina yaslanmaktadır.

Öncelikle gerek Anayasanın mevcut şeklinden gerekse 6771 sayılı kanunun kaleme alınış biçiminden yeni sistemde yürütmeye tanınmış bir mahfuz alanın bulunduğu sonucuna ulaşılmasının mümkün olmadığı belirtilmelidir. Öğretide pek çok yazarın ifade ettiği gibi Anayasanın metninden böyle bir anlamın çıkarılması, önemli ölçüde zorlama bir çabanın neticesi olacaktır. Nitekim böylesine bir çıkarım, salt lafzi yoruma başvurulması durumunda akla gelebilse de, hukuk normlarının tefsirinde yalnızca lafzi yoruma başvurulmasının çoğu durumda yetersiz veya hatalı sonuçlara yol açacağı bilinen bir gerçektir. Zira bu konuda Anayasanın ilgili bütün hükümleri, Anayasada kendisine yer bulan prensipler (dolayısıyla sistematik yorumdan süzülen Anayasanın genel ruhu ve anlamı), değişiklik metninin hazırlık çalışmaları ve gerekçeler (Anayasa koyucunun iradesini gösteren tarihi yorum) ve ilgili hükümlerin barındırdığı amaç (gaî yorum) gibi kriterler dikkate alındığında, hiçbir şekilde açıkça hüküm altına alınmamış olan mahfuz alan sonucuna varılmasını gerektirecek bir sebebe denk gelmek mümkün değildir. $\mathrm{Bu}$ kapsamda anayasa ve idare hukuku literatüründe serdedilmiş olan ve yukarıda naklettiğimiz bütün gerekçelere eksiksiz katılmaktayız. Hâliyle söz konusu açıklamaları, burada tekrar etmeye gerek bulunmamaktadır.

Burada asıl üzerinde durmak istediğimiz konu, mahfuz alan sorusunun cevaplanması yolunda karşılaştırmalı hukuktan elde edilen ve yukarıda görüldüğü üzere bazı yazarlarca da bir argüman olarak değinilen Fransız sistemindeki kararname gücü ile kanun koyma yetkisi arasındaki ilişkinin mahiyeti ve bu ilişkinin zamanla uygulama ve yargı eliyle nasıl bir halete büründürüldüğü hususudur. Yürütmeye ait münhasır bir alanın söz konusu olamayacağ1 noktasında dile getirilen diğer gerekçeler, pek çok çalışmada etraflıca ve defalarca ele alınmış ve açıklanmış olmasına rağmen, bu nokta hâlen daha izah edilmeye, berrak kılınmaya ve Türk hukuk dünyasına tanıtılmaya muhtaç durumdadır. Çünkü bu bilgi, yeni Türk sisteminde neden 
mahfuz bir düzenleme alanı bulunamayacağının açıklığa kavuşturulmasında hatırı sayılır bir veri olarak kendini göstermektedir.

Böylesine bir mukayesenin doğru bir şekilde hayata geçirilebilmesi için, yabancılık içinde olunan Fransız rejiminin, pozitif hükümler, uygulama, doktrin ve yargı kararları yönünden kavranmış olması lazımdır. Gerçekten herhangi bir sisteme yönelik çıkarım yapabilmek için ilk olarak o sistemin dayandığı yapının anlaşılması zaruret taşır. Bu zorunluluk karşısında önce Fransa' da 1958 Anayasasının nasıl bir rejim kurduğu, akabinde bu yapının nasıl bir dönüşüm seyri izlediği kısaca anlatılacak ve bu verinin Türkiye'de yeni karşımıza çıkan mahfuz alan tartışması bağlamındaki katkısı açıklanacaktır. ${ }^{\text {ii }}$

04 Ekim 1958 tarihli Fransız V. Cumhuriyet Anayasasında kendine yer bulan pek çok reformist düzenleme içinde kanun ve kararnamelere ilişkin kurgunun, Anayasanın daha ilk ortaya çıktığı andan beridir yeni Cumhuriyetin en dikkat çekici ve devrimci yeniliklerinden biri olarak anlaşıldığını söyleyebilmek mümkündür (De Soto, 1959, s. 240; Chrétien, Chifflot ve Tourbe, 2019, s. 183). Nitekim Anayasanın metninden ve ruhundan kolaylıkla anlaşılan yürütmeyi güçlendirme temayülü ve bu kapsamda Anayasaya yerleştirilen rasyonelleştirilmiş parlamenter düzene ilişkin çarpıcı mekanizmalar arasında kuşkusuz en dikkat çekici olan husus olarak sabık Cumhuriyet anayasalarında açık bir vurguyla düzenlenen ve fakat 1958 yılına gelindiğinde III. ve IV. Cumhuriyet dönemlerinde siyasi istikrarsızlık yüzünden yaşanan kötü tecrübelerin kaynağı olarak anlaşılmaya başlanan parlamentonun üstünlüğü prensibinin yeni Anayasa tarafindan bütünüyle alaşağı edilmiş olması gösterilmektedir (Debré, 1959, s. 8-17). Böylelikle 1876 Fransız ihtilalinden itibaren bütün haşmetiyle zihinlerde yaşayan Parlamentoya ait sınırsız düzenleme iktidarı ve bu bağlamda yasama merkezcilik (légicentrisme) tasavvuru, V. Cumhuriyet ile birlikte ortadan kalkmaktadır (Chantebout, 2015, s. 562; Le Pourhiet, 2018, s. 448). Çünkü Parlamentonun kanun yapma iktidarı önünde herhangi bir sınırlama getirmeyen, dolayısıyla yasama yetkisinin genelliği prensibine dayanan önceki anayasaların aksine olarak 1958 Anayasası, ilk defa olarak düzenleme alanının çeşitli konu başlıklarına göre tasnif etmekte ve hangi hususlarda kanun çıkarılacağını önceden tek tek belirleme yoluna gitmektedir. Nitekim 34. maddeye bakıldığında yasama organının hangi konularda kanun çıkarabileceğinin başlık başlık sayılmak suretiyle bir liste hâlinde önceden tespit edildiği görülür. Öte yandan Anayasada kanunla düzenleneceği belirtilen başka hususlar da bulunmakta, ayrıca anayasallık blokuna dâhil bir norm tarafından kanunla düzenleneceği öngörülen konular da Parlamentonun yetkisinde bulunmaktadır (Oliva ve Giummarra, 2017, s. 256). Ancak kaynağını gerek Anayasadan gerek 1789 İnsan Hakları Beyannamesi gibi anayasallık blokunun parçası olan bir normdan alsın, bütün bu konuların önceden saptanmış olduğu, böylelikle kanun koyucunun 
düzenleme alanını belirli bir çerçeve içinde kalmak suretiyle sınırlandırdı $\breve{g ̆}_{1}$ açıktır. Öyle ki Anayasa koyucunun, bu hükümlerle Parlamentoyu hudutları önceden tespit edilmiş belirli bir mıntıkaya hapsetmek istediği söylenebilir (Wahl, 1959, s. 40).

1958 Anayasası kanun alanını çerçeveleyen bu kurguyla yetinmemiş, 37. madde ile kanunun düzenleme sahası dışında kalan bütün konuların kararname alanını teşkil edeceğini açıkça hüküm altına almıştır. Dahası Anayasa, konu temelinde hayata geçirdiği anılan yetki bölüşümüyle de iktifa etmemekte, tasarlanan bu örüntünün ihlal edilmemesi için de elinden geleni yapmaktadır. Gerçekten bu istikamette biri önleyici (m. 41), diğeri telafi edici (m. 37/2) olmak üzere son derece etkili iki silah yürütme organına bahşedilmektedir (Güller, 2020, s. 5768). Öyle ki Anayasanın yürütmeye tanıdığı bu imkânlar muvacehesinde hükûmet, şayet arzu ederse, kararname alanına dâhil olduğunu düşündüğü bir kanunun çıkarılmasını ister önceden, isterse herhangi bir zamanla sınırlı olmaksızın sonradan net bir biçimde engelleyebilecek konumdadır (Mélin-Soucramanien ve Pactet, 2020, s. 670). Hâl böyleyken kararname alanının Parlamentoya karşı korunması noktasında bu denli hassas olan aynı Anayasa, yasama organına kararname yetkisini kullanan yürütme tarafından gelebilecek tehditler karşısında müracaat edebileceği hiçbir özel yol tanımamıştır. Bu durumlarda kanun alanının korunması, yalnızca genel hükümler kapsamında idari yargıda açılacak iptal davası yoluyla sağlanabilmektedir (Chapus, 2001, s. 72; Verpeaux, 2015, s. 593). İşte bu anayasal tasarım dolayısıyla literatürde, 1958 metninin Parlamentonun yasama yetkisini istisna hâline getirdiği ve yürütmenin düzenleme gücünü kural seviyesine çıkardığı belirtilmiştir (Favoreu, Gaïa, Ghevontian vd, 2020, s. 861; Plessix, 2018, s. 724; Chapus, 2001, s. 69; Jacqué, 2018, s. 231).

Anayasanın ihtiva ettiği bu kurgulama, yukarıda yeni Türk sisteminde yürütmeye tahsis edilmiş bir düzenleme alanının bulunmadığı sonucunun çıkarılmasında önemli bir argüman olarak karşımıza çıkar. Çünkü eğer böyle bir maksat söz konusu ise, anayasa koyucu tıpk1 Fransız V. Cumhuriyet Anayasasında olduğu gibi açık ve net bir biçimde bunu ortaya koymuş olmalıdır. Dolayısıyla böyle bir sonucun yorumla çıkarsamaya kalmaması ve anayasanın sarih düzenlemesine konu olması beklenir. Nitekim Fransa'da da literatürün yukarıda aktarılan tespitleri, Anayasadan zorunlu olarak çıkan manadan başkası değildir. Öte yandan Fransız sitemini önemli kılan ve bizi de bu açıklamaları yapmaya sevk eden, yalnızca Anayasada yer alan bu tasarımdan ibaret değildir. Zira ülkede uygulama, yargı kararları ve öğreti el ele vermek suretiyle, Anayasada yer alan bu kurguyu bambaşka bir halete büründürmüş ve yasama organının yetki alanını, belki de Anayasanın metninde hiç de kastedilmeyen bir şekilde genişletmiştir. 34 ve 37. madde ile tasarlanan şemanın baştan aşağıya esnetildiği bu pratiğin, ilk olarak doktrinde daha sonra ise son derece radikal sayılabilecek içtihatlar aracılığıyla yargı 
organınca da kabul gördüğü anlaşılmaktadır. Bu bağlamda Anayasanın metni uyarınca kararname sahasında olduğu şüphe götürmeyen konular muhtelif saiklerle kanunla düzenlenmeye başlamış, uygulamada tebellür eden yasamanın genişleyen düzenleme alanına hem doktrin hem de yargı içtihatları olumlu tepkiler vermiştir (Güller, 2020, s. 81 vd.). Bu doğrultuda ilk olarak belirtilmesi gereken kuşkusuz Anayasa Konseyinin Anayasanın kararname alanına bıraktığı konularda çıkarılmış olan kanunların Anayasaya aykırı olmayacağı yönündeki 1982 tarihli kararıdır. ${ }^{\text {iii }}$ Bu içtihatla birlikte artık Parlamentonun, Anayasal kurgunun kendi düzenleme sahasının dışında görerek kararname yetkisine bıraktığı konularda istediği gibi kanun çıkarmasının önü açılmış olmaktadır. Çünkü yasama organının yürütmenin yerine geçerek onun yetki sahasında düzenleme yapması durumunda herhangi bir müeyyide doğmayacaktır (Saccone, 1987, s. 171). Dahası düzenleme alanının yatay bir biçimde paylaştırıldı̆̆ı anayasal tasarımdan farklı olarak, Mahkemenin kararıyla birlikte, kanunların kararnemeler karşısında tartışılmaz bir üstünlüğe eriştiği söylenebilir (Mathieu, 2005, s. 74). $\mathrm{Bu}$ durumda artık Fransız sistemi açıdından münhasır bir kararname alanının mevcut olmadığını tespit edebilmek mümkün olmaktadır (Favoreu, 1987, s. 882; Verpeaux, 2015, s. 600; Pezant, 1984, s. 925). Bundan başka Anayasa Konseyinin zaman içinde vermiş olduğu 34. maddenin geniş bir yorumla anlaşılması, kanun alanının 34. maddeye indirgenmemesi, temel hakların korunması bağlamında kanun alanının genişletilmesi ve menfi yetkisizliğe ilişkin içtihatlarının da Parlamentonun yetki alanını, anayasal kurgunun çok daha ötesine taşıdığını söyleyebilmek mümkündür. Binaenaleyh 1958 Anayasasının en başta gelen yeniliklerinden biri olarak kabul edilen kanun ve kararname sahalarının ayrıştırılmasına ve özellikle kararname alanının korunmasına dair tasarımın, gerek uygulamada gerekse yargı içtihatlarında herhangi bir karşılık bulmadığı rahatlıkla söylenebilecektir. Bu tespiti Rivero, oldukça ün kazanan, “1958 Anayasasının devrimi gerçekleşmemiştir”, sözüyle veciz bir şekilde ortaya koymuştur (Rivero, 1978, s. 263). Aynı saptayışın, o tarihten itibaren Fransa'da kamu hukuku alanında kaleme alınan hemen her çalışmada tekrar edildiğini gözlemleyebilmek mümkündür (Örnek sadedinde bkz. (Favoreu, Gaïa, Ghevontian vd, 2020, s. 861 vd; Verpeaux, 2015, s. 588; Chapus, 2001, s. 70; Mélin-Soucramanien ve Pactet, 2020, s. 664; Oliva ve Giummarra, 2017, s. 269; Le Pourhiet, 2018, s. 449 vd; Haquet, 2019, s. 321; Mathieu, 2005, s. 76; François, 1997, s. 394; Avril, 1981, s. 18; Pezant, 1984, s. 922; Plessix, 2018, s. 729; Drago, 2015, s. 176; (Peiser, Dubouis ve Négrin, 2017, s. 102-103).

Türkiye'de 2017 Anayasa değişiklikleriyle kabul edilen Cumhurbaşkanlığı kararnamesi çıkarma yetkisinin anayasal çerçevesine göz atıldığında ise bütünüyle farklı bir kurgulamaya rast gelinmektedir. Gerçekten 6771 sayılı kanunda, ne Meclisin düzenleme alanının 
sınırlandırılması ve böylece yasama yetkisinin genelliği ilkesinin dönüşmesi neticesini doğuracak bir değişiklik yapılmış, ne de belirli hususların münhasıran kararname ile düzenleneceği açık bir şekilde hüküm altına alınmıştır. Filhakika yasama gücünün TBMM'ye ait olduğunu ve devredilemeyeceğini söyleyen 7. madde ile yürütme yetkisinin kanunlara uygun olarak kullanılacağını buyuran 8. maddenin aynen muhafaza edildiği görülmektedir. Öte yandan Parlamentonun yetkilerini düzenleyen ve Fransız Anayasasındaki meşhur 34. maddenin muadili olan 87. maddeye de en ufak bir dokunuşta bulunulmadığı belirtilmelidir. Nitekim bu maddede, 1958 Anayasasının 34. maddesinden farklı olarak, yasama organının kanun koyacağı soyut ve mutlak olarak ifade edilmekte ve yetkinin herhangi bir konu temelinde belirlenmesi ve böylelikle tahdidi yoluna gidilmemektedir. Dolayısıyla, kanun koyar yolundaki bu genel ifadenin bir sonucu olarak yasama organının 2017 öncesinde olduğu gibi istediği konuda kanuni düzenleme yapması mümkün olacaktır.

6771 sayılı Anayasa değişikliği kanunun 1982 Anayasasında yasama ve yürütme yetkisinin karş1lıklı konumuna ilişkin bahse konu hükümleri bile Fransız sisteminde kanun ve kararname ilişkisine yönelik rejimin tam tersi bir yerde durduğu sonucuna ulaşmak için tek başına yeterliyken, 104. maddenin 17. fikrası ile örgülenen Cumhurbaşkanlığı kararnamelerine ilişkin anayasal çerçeve ile birlikte Türk sisteminde 1958 Anayasasının tam aksi yönde çok daha ileri bir noktaya gidilmiş olmaktadır. Nitekim bu fikrada münhasıran kanunla düzenlenmesi öngörülen hususlarda Cumhurbaşkanlığı kararnamesi çıkarılması yasaklandığı gibi, son derece çarpıcı bir hüküm olarak, CBK ile düzenlenmiş bir meselede sonradan kanun konulması hâlinde, kararnamenin hükümsüz hâle geleceği açıkça hüküm altına alınmaktadır. Bu nevi bir kayıtlama, Fransız sistemi bakımından asla bahis konusu edilemeyeceği gibi, aksine 1958 Anayasası kararname sahasında kalan bir hususta kanun yapılmasına engel olmak için deyim yerindeyse elinden gelen her şeyi yapmış, yürütme organına bu yolda iki ayrı düzenek bahşetmiştir. Dolayısıyla 1958 Fransız Anayasa koyucusu, açık ve seçik bir şekilde norm koyma alanını kanun ve kararname arasında bölüştürdükten sonra, yasamaya bırakılan sahanın yürütmeye karşı korunması kapsamında en ufak bir hüküm içermezken, tersine olarak yürütmenin düzeleme alanını yasamadan gelebilecek tecavüzlere karşı korumak yolunda önleyici ve telafi edici olmak üzere iki tesirli mekanizma getirmek suretiyle, kararname gücü lehinde bir yazım tarzı benimsemişken, Türkiye'de ise 2017 tarihinde beliren tali Anayasa koyucu, CBK alanını koruyacak bir üslup yerine bütünüyle kanunu öne çıkaracak bir vurgu içermektedir. İşte bu mukayese, kanun ve kararname alanları bakımından bir ayrıştırma meydana getirilmek istendiğinde bunun nasıl yapılacağını göstermek ve Türkiye'de 2017 
Anayasa değişikliğiyle getirilen çerçevenin böylesine bir yazım şeklinden ne kadar uzak olduğunu ortaya koymak bakımından son derecede değerlidir.

Bununla birlikte iki Anayasa arasındaki belirgin redaksiyon ayrılığını saptamakta yetinilmemesi icap eder. Zira anılan karşılaştırmada altı çizilmesi gereken başka bir nokta daha bulunmaktadır. Gerçekten Fransa'da 1958 Anayasasının barındırdığı Parlamento aleyhine tasarlanmış son derece sarih vurguya karşılık, gerek uygulamayla, gerekse doktrin ve yargı içtihatlarıyla hayata dökülen kanunun yeniden güçlenmesini ve eski kuvvetine kavuşmasını sağlayıcı yaklaşım oldukça değerlidir. Buna göre, yukarıda değinildiği gibi, 1958 Anayasasının kurguladığı açık çerçeveye rağmen münhasır bir kararname alanı düşüncesi gerçek hayatta taraftar bulmamış, ne kadar güç de olsa, yasama organının lehine kayda değer bir hukuki duruş ve kanun yararına bir tavır sergilenebilmiştir. Oysa Türkiye'de 1958 Anayasası metninin zıddına, Cumhurbaşkanlığ k kararnamesine tahsis edilen bir düzenleme sahasının varlığına dönük Anayasada hiçbir açık seçik hüküm bulunmadığı hâlde ve şimdiye kadar ortaya çıkan emarelerin uygulayıcıların da böyle bir kanıya sahip olmadığını göstermesine karşılık, literatürde bazı başlıklar yönünden yürütme kuvvetine tanınmış münhasır bir alanın mevcut olduğu kanaatine yorum yoluyla erilmeye çalışıldığı görülmektedir. Böyle bir yaklaşımın Anayasanın ruhuyla bağdaşmadığını söyleyebilmek mümkündür.

Nitekim gerek öğretide serdedilen görüşler, gerekse Anayasa Mahkemesinin CBK'nın denetimi kapsamında şu ana kadar verdiği kararlar incelendiğinde, şimdiden bu cihette bir temayülün doğmuş olduğu görülmektedir. Zira yukarıda gösterilen literatürde ortaya konulmuş önemli gerekçelere ilaveten Anayasa Mahkemesi de yeni dönemde vermiş olduğu kararlarında mahfuz alan tezini kabul etmediğini beyan etmektedir. Gerçekten Mahkeme, bu konuya ilişkin 23.1.2020 tarihli kararında şöyle demiştir:

Anayasa'da olağan dönemde CBK ile düzenleneceği özel olarak belirtilen konuların Anayasa'nın 104. maddesinin on yedinci fikrasında CBK'lar için öngörülen sınırlamalara tabi olmayacağına ilişkin herhangi bir hükme yer verilmemiştir. Dolayısıyla Anayasa'nın 104. maddesinin on yedinci fikrasında CBK'lar için getirilen sinırlamalar, Anayasa'da CBK ile düzenleneceği özel olarak belirtilen konular için de geçerlidir. ${ }^{i v}$

Bu durumda Anayasa Mahkemesinin de CBK ile düzenleneceği özel olarak ifade edilen konuların, yürütmeye tahsis edilmiş münhasır bir alana vücut verip vermediği tartışmasında, böyle bir sahanın mevcut olmadığı yaklaşımına teveccüh ettiği görülebilmektedir. Dolayısıyla ülkemizde gerek uygulamanın şu ana kadar takındığı tavır, gerekse AYM'nin ilk kararları dikkate alınarak, Anayasanın ruhuna hiçbir şekilde uymayacak olan mahfuz düzenleme alanın mevcut olmadığ ve 6771 sayılı kanunla birlikte ülkemizde önemli bir anayasal ilke olarak 
varlık bulan yasama yetkisinin genelliği prensibine halel getirecek herhangi bir değişikliğin yapılmadı̆̆ kabul edilmelidir.

\section{Sonuç}

Yeni Türk sisteminde kanun ve kararname ilişkisi bakımından belki de en netameli mesele olarak görülebilecek olan yasamaya kapatılarak yürütmenin düzenleme yetkisinin tekeline bırakılmış bir alanın var olup olmadığı sorusuna ilişkin literatürde serdedilmiş olan muhtelif açıklamalar gösterilmiştir. Bu noktada her iki yönde görüşlerin de çok sayıda yazar tarafından savunulduğu dikkat çeker. Bununla birlikte 1982 Anayasasının 6771 sayılı kanunla eriştiği yeni metninden ferah fahur çıkarılamayan, yalnızca ilgili dört maddenin lafzen katı yorumlanması durumunda akla gelebilen ama yine de kesin ve zaruri bir mana içermeyen bu sonucun, Anayasanın sistematik, tarihi ve gaî yorumuna uygun olmadığı belirtilmelidir. Ayrıca karşılaştırmalı hukuk verileri de bu doğrultuda bir çıkarıma varmayı önemli ölçüde zorlaştırır.

Nitekim Türkiye'de 2017 Anayasa değişiklikleriyle beliren yeni düzende, Cumhurbaşkanlığı kararnameleri ile kanun arasındaki ilişkinin, gerek 1982 Anayasasının özgün metnine yer alıp referandumda herhangi bir dönüşüme uğratılmamış önceki hükümler, gerekse değişiklikle birlikte kabul edilen yeni maddeler muvacehesinde, yürütmeye terkedilmiş mahfuz bir alanın varlığını ortaya koyacak isabetli bir gerekçe mevcut değildir. Bir kere 6771 sayılı kanun, Anayasanın yasama yetkisinin genelliğini ve yürütmenin yasamaya bağlılığını düzenleyen 7,8 . ve 87. maddelerine hiçbir suretle dokunmadığı gibi, CBK'ların çerçevesini çizdiği 104. maddenin 17. fikrasında da kanunu açıkça kararnamelerden üstün bir şekilde ele almıştır. Bu bağlamda yürütme yetkisine tanınan kararname çıkarma gücüne karşı getirilmiş en kavi sınırlamalardan biri olarak Anayasada kanunla düzenleneceği belirtilen hususlarda CBK çıkarılamayacağına yönelik kayıtlama gösterilebilir. Bu noktada Anayasanın 123. maddesi son derece ilginç bir yerde konumlanır. Çünkü burada başından beri belirtildiği ve 6771 sayılı kanunla da aynen korunduğu üzere, idarenin kuruluşu ve düzenlenişi ancak kanunla yapılabilecektir. Şu hâlde Anayasada başka bir hüküm olmasaydı, md. 104/17 ile md. 123/1'in birlikte yorumlanması neticesinde idareye ilişkin konularda CBK çıkarılamayacağı sonucuna varmak gerekirdi. Ancak görüldüğü üzere 6771 sayılı kanun ile Anayasanın dört maddesine 123. maddedeki yasağı aşmak ve kararname çıkarmaya kapı aralamak için bir istisna yerleştirilmiş olmaktadır. Bu durumda ilgili maddelerin, birer istisna olmaları sebebiyle dar yorumlanıp, yalnızca idarenin düzenlenmesi işinin CBK ile yapılamayacağı yolundaki anayasal engelin aşılmasına hizmet etmesi ve çok daha ileri gidilerek bu yetkinin asıl sahibi olan yasama organının devre dışı bırakılamaması icap eder. Gerçekten Meclisin anayasaya uygunluk dışında bir kayıtlama içermeyen yasama yetkisine ilişkin hükümler bu denli açık ve ortadayken, CBK 
çıkarılmasına imkân sağlamak için konulduğu anlaşılan maddelerden yorumla bir yasama engeli çıkarmak, hukuk tekniğine uygun olmasa gerektir.

Anayasal çerçeveden açıkça süzülen bu sonuca Fransız sisteminde elli yıldan uzun bir zamandır yaşanan gelişmeler de 1şık tutmaktadır. Bu itibarla 1958 Anayasasının maddelerinde Parlamento aleyhine ortaya konulmuş olan sarih kurgulamaya rağmen, uygulama ile doktrinin ve yargı kararlarının, tam tersine kanun lehine bir pratiğe vücut vermiş olması dikkate alındığında, yeni Türk rejiminde yasama organının, anayasal çerçeve bakımından Fransa'ya göre çok daha avantajlı bir konumda yer alması sebebiyle, bizde de benzer bir yaklaşımın benimsenmesinin evleviyetle mümkün olduğu, bu bakımdan Fransız sisteminin, yeni sistemde yürütmeye verilmiş münhasır bir düzenleme yetkinin bulunmadığını savunmak yolunda önemli çıkarımlar sunduğu ortaya çıkmaktadır. Üstelik ülkemiz bağlamında benzer bir tavrın yeğlenmesi, 2017 Anayasa değişikliğiyle yeni bir yapıya bürünen 1982 Anayasasında, Meclisin 1958 Anayasasına kıyasla çok daha elverişli bir konuma sahip olduğu göz önünde tutulursa, en ufak bir zorluk dahi içermez. Dolayısıyla Fransız anayasal düzeninin açıkça kanuna karşı kararnameyi öncelemesine rağmen, hukuk aktörleri yasama organı lehine bir okumaya ve kanunun uygulama alanının giderek genişlemesi sonucunu beraberinde getiren pratiklere yönelmiş olmaları, Türk öğretisi ve uygulaması açısından da yabana atılamayacak bir numune oluşturmaktadır. Kanun-kararname çatışması gündemine 2017 reformuyla birlikte gelmiş olan Türk hukuk dünyasının benzer bir duruşu göstermesinin, pozitif hükümler çerçevesinde çok daha mümkün ve dahası gerekli olduğu açıktır.

\section{Kaynakça}

Açıl, M. (2018). 2017 Anayasa Değişiklikleri Çerçevesinde Cumhurbaşkanlığı Kararnameleri. İstanbul Hukuk Mecmuasl, 76(2), 725-756.

Akartürk, E. A. (2020). 2017 Anayasa Değişikliğinin "Parlamentosuzlaştırma" Etkisi Üzerine. Yeditepe Üniversitesi Hukuk Fakültesi Dergisi, XVII(1), 1-26.

Aksoylu Ürger, Ö. (2018). Son Anayasa Değişiklikleri Uyarınca Cumhurbaşkanlığı Kararnamesinin Türk Hukukundaki Yeri. K. Şenocak (Dü.), 4. Uluslararası Hukuk Sempozyumu Tam Metin Kitabı içinde, (s. 137-160). Alanya.

Akyılmaz, C. (2019). 2017 Anayasa Değişikliğine Göre Cumhurbaşkanlığı Kararnameleri. Ankara Hacı Bayram Veli Üniversitesi Hukuk Fakültesi Dergisi, XXIII(1), 191-207.

Anayurt, Ö. (2019). Anayasa Hukuku Temel kavramlar ve Türk Anayasa Hukuku. Ankara: Seçkin Yayınları.

Ardıçoğlu, M. (2017). Cumhurbaşkanlığı Kararnamesi. Ankara Barosu Dergisi, 2017(3), 19-51.

Aslan, V. (2019). Cumhurbaşkanlığı Kararnamelerinin Kanunlara Uygunluğunun Denetimi ve Çeşitli Hususların Kararnamelerle Düzenleneceğinin Kanunlarda Belirtilmesi Üzerine. Anayasa Yargısl, 36(1), 139-161.

Atar, Y. (2019a). Türk Anayasa Hukuku. Ankara: Seçkin Yayıncılık. 
Atar, Y. (2019b). Cumhurbaşkanlığı Kararnamelerinin Hukuki Rejimi ve Anayasallık Denetimi. Anayasa Yargısı, $36(1), 241-259$

Atay, E. (2019). İdare Hukuku. Ankara: Seçkin Yayınları.

Avril, P. (1981). Le parlement législateur. Revue française de science politique, 15-31.

Azaklı, M. (2019). Cumhurbaşkanlığı Kararnamelerinin Somut Norm Denetimi Yoluyla İncelenmesi. Anayasa Yarglsl, 36(1), 73-103.

Barın, T. (2020). Cumhurbaşkanlı̆̆ Kararnamelerinin Hukuki Rejimi ve Anayasallık Denetimi. İstanbul: On İki Levha Yayıncılik.

Can, O. (2020). Cumhurbaşkanlığı Kararnamelerinin Hukuki Rejimi Anayasa Mahkemesi Yaklaşımı. Anayasa Yargısı, 37(1), 133-192.

Chantebout, B. (2015). Droit constitutionnel. Paris: Dalloz.

Chapus, R. (2001). Droit administratif. Paris: Montchrestien.

Chrétien, P., Chifflot, N., \& Tourbe, M. (2019). Droit administratif. Paris: Sirey.

Çıtak, H. (2019). Cumhurbaşkanlığı Kararnameleri Karşısında İdari Yargıcın Konumu. Genç Hukukçu Araştırmacılar Sempozyumu (s. 33-50). İstanbul: On İki Levha Yayınları.

De Soto, J. (1959). La loi et le règlement dans la constitution du 4 octobre 1558. Revue du droit public.

Debré, M. (1959). La nouvelle constitution. Revue française de science politique, 9(1), 7-29.

Drago, G. (2015). Le domaine de la loi : Brève histoire d'une dérive constitutionnelle. L'intérêt général, Mélanges en l'honneur de Didier Truchet (s. 169-185). içinde Paris: Dalloz.

Duman, B. (2019). Cumhurbaşkanlığı Kararnameleri; Hukuki Niteliği, Rejimleri, Denetimi ve Mukayeseli Hukuktaki Yeri. Anadolu Üniversitesi Hukuk Fakültesi Dergisi, 5(2), 537-592.

Eren, A. (2019). Anayasa Mahkemesinin Kanun Hükmünde Kararnamelere İlişsin İçtihadı Doğrultusunda Cumhurbaşkanlığg Kararnamelerinin Değerlendirilmesi. Anayasa Yargısl, 36/1, 1-72.

Favoreu, L. (1987). Les règlements autonomes n'existent pas. Revue française de droit administratif.

Favoreu, L., Gaïa, P., Ghevontian, R., \& Mestre, J.-L. (2020). Droit constitutionnel. Paris: Dalloz.

Fendoğlu, H. T. (2019). Cumhurbaşkanlığı Kararnameleri Mahfuz Düzenleme Alanı mıdır? Ankara Barosu Dergisi, 2019(3), 277-310.

Fendoğlu, H. T. (2020). Anayasa Hukuku. Ankara: Yetkin yayınları.

François, B. (1997). "Le Conseil constitutionnel et la Cinquième République, Réflexion sur l'émergence et les effets du contrôle du constitutionnalité en France. Revue française de science politique, 47(5), 377-404.

Gözler, K. (2019a). Türk Anayasa Hukuku Dersleri. Bursa: Ekin Yayınları.

Gözler, K. (2019b). Türk Anayasa Hukuku. Bursa: Ekin Yayınları.

Güller, A. (2020). Cumhurbaşkanlı̆̆ı Kararnameleri. Ankara: Yetkin Yayınları.

Günday, M. (2017). İdare Hukuku. Ankara: İmaj Yayınları.

Haquet, A. (2019). Droit constitutionnel. Paris: Dalloz.

İba, Ş. (2018). Türk Anayasa Hukuku. Ankara: Turhan Kitabevi. 
Jacqué, J.-P. (2018). Droit constitutionnel et institutions politiques. Paris: Dalloz.

Kanadoğlu, K. (2018). Cumhurbaşkanlığı Kararnamesi. Galatasaray Üniversitesi Hukuk Fakültesi Dergisi, 2018(1), 637-650.

Keskinsoy, Ö., Kaya, S., \& Meri, T. (2020). Cumhurbaşkanlığı Kararnamesi. Ankara SBF Dergisi, 75(4), 13831416.

Küçük, A. v. (2019). Türkiye'de 2017 Anayasa Değişikliği Kapsamında Yürürtmenin Asli Düzenleme Yetkisi ve Mahfuz Düzenleme Alanı. Süleyman Demirel Üniversitesi Hukuk Fakültesi Dergisi, 9(1), 1-60.

Le Pourhiet, A.-M. (2018). Droit constitutionnel. Paris: Economica.

Mathieu, B. (2005). La part de la loi, la part du règlement De la limitation de la compétence réglementaire à la limitation de la compétence législative. Pouvoirs, 3, 73-87.

Mélin-Soucramanien, F., \& Pactet, P. (2020). Droit constitutionnel. Paris: Sirey.

Narter, R. v. (2020). Hukuk İhdası Rejiminde Cumhurbaşkanlı̆̆ı Kararnamesi. Ankara: Yetkin Yayınları.

Okşar, M. (2019). 2017 Anayasa Değişiklikleri Çerçevesinde Yürütme Erkinin Üstünlüğü. Ankara: Yetkin Yayınları.

Oliva, É., \& Giummarra, S. (2017). Droit constitutionnel. Paris: Dalloz.

Özbudun, E. (2017). Türk Anayasa Hukuku. Ankara: Yetkin Yayınları.

Özbudun, E. (2019). Anayasa Mahkemesinin 57. Kuruluş Yıldönümü Nedeniyle Düzenlenen "Cumhurbaşkanlığ Kararnamelerinin Hukuki Rejimi ve Anayasallık Denetimi" Konulu Sempozyum. Anayasa Yarglsl, 36(1).

Özdemir, H. E. (2019). Cumhurbaşkanlığı Kararnamelerinin Hukuki Çerçevesi. İstanbul Medipol Üniversitesi Hukuk Fakültesi Dergisi, 6(1), 265-282.

Peiser, G., Dubouis, L., \& Négrin, L.-P. (2017). Droit public. Paris: Dalloz.

Pezant, J.-L. (1984). Loi/règlement, la construction d'un nouvel équilibre. Revue française de science politique, 4$5,92-954$.

Plessix, B. (2018). Droit administratif général. Paris: LexisNexis.

Rivero, J. (1978). Rapport de syntèse. Vingt ans d'application de la Constitution de 1958 le domaine de la loi et du règlement, Colloque organisé par la Faculté de Droit et de Science Politique d'Aix-Marseille sous la direction de Louis Favoreu. Aix-Marseille: Presse Universitaire d'Aix-Marseille.

Saccone, G. (1987). La répartition des compétences entre pouvoir législatif et pouvoir réglementaire. Annuaire international de justice constitutionnel, 1-1985, 169-182.

Sever, D. (2020). Cumhurbaşkanının Teşkilatlanma Konusundaki Yetkileri ya da "Parthenogenesis" Olmak. Kamu Hukukçuları Platformu Tam Metin Bildiri Kitabı (s. 353-389). İstanbul: On İki Levha Yayınalrı.

Sevgili Gençay, F. (2020). Kanun ve Cumhurbaşkanlığı Kararnamelerinin Karşılıklı Mahfuz Alanları Meselesi (Türkiye-Fransa Karşılaştırmalı Çalışma). Kamu Hukukçuları Platformu Tam Metin Bildiri Kitabı (s. 237-274). İstanbul: On İki Levha Yayınları.

Sezer, A. (2019). Normlar Hiyerarşisi ve Cumhurbaşkanlığı Kararnameleri (Çok Boyutlu Normlar Piramidi Yaklaşımı). Anayasa Yargısı, 36(1), 353-412.

Söyler, Y. (2018). Yeni Başkanlık Sisteminde Cumhurbaşkanlı̆̆ı Kararnamesi. Ankara: Seçkin Yayınları.

Şirin, T. (2018). İşlemeyen Sistemlerin Fonksiyonel Olmayan yanıtı. Anayasa Hukuku Dergisi, 7(14), 289-356.

Tan, T. (2018). İdare Hukuku. Ankara: Turhan Kitabevi. 
Tanör, B., \& Yüzbaşığlu, N. (2019). 1982 Anayasasına Göre Türk Anayasa Hukuku. İstanbul: Beta Yayınları.

Tekinsoy, A. (2020). Cumhurbaşkanlığı Kararnamelerinin Yürütmenin Mahfuz Düzenleme Yetkisi Açısından Değerlendirilmesi. Kamu Hukukçuları Platformu Tam Metin Bildiri Kitabı (s. 389-413). İstanbul: On İki Levha yayınları.

Ulusoy, A. (2019). Yeni Türk İdare Hukuku. Ankara: Yetkin yayınları.

Ulusoy, A. (tarih yok). Aralık 2016 Anayasa Teklifi Neler Getiriyor, Neler Götürüyor? Octobre 2021 tarihinde Türk Anayasa Hukuku Sitesi: https://www.anayasa.gen.tr/ulusoy-anayasa-degisikligi.pdf adresinden alındı

Ülgen, Ö. (2018). Cumhurbaşkanlığı Kararnamelerinin Niteliği ve Türleri. Galatasaray Üniversitesi Hukuk Fakültesi Dergisi, 2018(1), 4-39.

Verpeaux, M. (2015). Droit constitutionnel français. Paris: Presses Universitaires de France.

Wahl, N. (1959). Aux origines de la Constitution. Revue française de science politique, 9(1), 30-66.

Yasin, M. (2019). Cumhurbaşkanlığı Kararnamelerinin Türk İdari Teşkilat Hukukuna Etkileri. Anayasa Yargısı, $36(1), 315-333$.

Yeniay, L. v. (2019). Türk Hukukunda Yürütme Organının Düzenleme Yetkisi ve Cumhurbaşkanlığı Kararnamesi. Anayasa Yargisl, 36(1), 105-138.

Yıldırım, T. (2017). Cumhurbaşkanlığı Kararnameleri. Marmara Üniversitesi Hukuk Fakültesi Hukuk Araştırmaları Dergisi, 23(2), 13-28.

Yıldırım, T. (2019). İdarenin Kanuniliği İlkesi Bağlamında Cumhurbaşkanlığı Kararnamelerinin Anayasal Sınırı. Anayasa Yargısı, 293-314.

Yılmaz, H. (2020). Cumhurbaşkanlığı Kararnamelerinin Konu Bakımından Yetki Sınırları. İstanbul Hukuk Mecmuası, 78(1), 225-263.

\footnotetext{
${ }^{\mathrm{i}}$ Raporun özgün metni için bkz. European Commission For Democracy Through Law, Turkey Opinion, CDL-AD(2017)005, Opinion No: 875/2017, https://www.venice.coe.int/webforms/ documents/default.aspx?pdffile= cdl-ad(2017)005-e (Erişim tarihi: 01.09.2021), s. 19-20.

ii Bu konuda Türk literatüründe yapılan çalışmalar eskiye oranla artmaya başlamıştır. İlgili dönüşüme ilişkin kapsamlı ve tafsilatlı bilgi edinmek için şu kaynaklara bakılabilir: Anayurt, Ö. (2019). 1958 Anayasasında Kanun Anlayışı Kanunun Genelliğinden "Sinırlı-Tahsisli Kanun”a Geçiş. Ankara: Seçkin Yayınları; Güller, A. (2020). Cumhurbaşkanlığ Kararnameleri. Ankara: Yetkin Yayınları; Sevgili Gençay, F. (2020). Kanun ve Cumhurbaşkanlığı Kararnamelerinin Karşılıklı Mahfuz Alanları Meselesi (Türkiye-Fransa Karşılaştırmalı Çalışma). Kamu Hukukçuları Platformu Tam Metin Bildiri Kitabı (pp. 237-274). İstanbul: On İki Levha Yayınları.

iii Anayasa Konseyinin 1982 tarihli kararının tam metni için bkz. Conseil constitutionnel, 30 juillet 1982, nº 82-143 DC, Loi sur les prix et les revenus, Recueil Cons. const., s. 57

iv Anayasa Mahkemesi, E. 2019/31, K. 2020/5, KT. 23.1.2020, RG. 13.5.2020, S. 31126, 25. paragraf vd. Mahkemenin, 106. maddenin 11. fikrasında CBK ile düzenleneceği özel olarak belirtilen bir hususu, 104. maddenin 17. fikrasındaki sınırlamalara uygunluk yönünden incelediği başka bir kararı için bkz. Anayasa Mahkemesi, E. 2019/105, K. 2020/30, KT: 12.6.2020, RG. 20.8.2020, S. 31219, 20. paragraf vd.
} 